Vol. 2, No. 2, 2020

https://doi.org/10.23939/jtbp2020.02.021

Lesya Vovk, Oksana Matsiyevska, Oleh Zhdanov

\title{
CHLORELLA VULGARIS IN WASTEWATER TREATMENT PROCESSES - PRACTICAL EXPERIENCE
}

\author{
Lviv Polytechnic National University, \\ Department of Hydraulic and Water Engineering, \\ oksanamatsiyevska@gmail.com
}

(C) Vovk L., Matsiyevska O., Zhdanov O., 2020

Wastewater from human settlements contains a significant amount of organic and biogenic substances. Insufficiently treated wastewater enters surface water and leads to their eutrophication. The usage of microalgae in wastewater treatment has significant advantages in comparison with other methods of removing biogenic substances. Namely: effective and simultaneous removal of nitrogen and phosphorus without reagents management facilities, oxygen formation. Using microalgae in wastewater treatment is a new environmentally friendly biotechnological method. Microalgae grow well in wastewater, from which they absorb pollutants. The purpose of the study is to analyze the work and determine the possibility of intensification of sewage treatment plants in the western region of Ukraine with a population of about 18,900 inhabitants. Productivity of treatment plant is $3400 \mathrm{~m}^{3} / \mathrm{day}$. Experimental investigation consisted in adding a concentrate of a living microalgae strain of the species Chlorella vulgaris to the wastewater that was entered to the treatment plant during MaySeptember 2019. During the research, the results of wastewater analyzes conducted by the chemical laboratory of the municipal water supply and sewerage company were used. The results of the survey and analysis of the city's treatment plant indicate an insufficient degree of wastewater treatment. The effectiveness of Chlorella vulgaris at the treatment plant has been experimentally proven. Mathematical dependences of the effect of wastewater treatment (using Chlorella vulgaris) on their temperature according to the indicators: $\mathrm{BOD}_{5}, \mathrm{COD}$, concentration of ammonium nitrogen, phosphates and suspended solids were obtained. Dependencies are described by a linear function that characterizes the general behavior of the obtained data. The obtained results made it possible to significantly reduce the negative impact of treatment plants on the environment.

Key words: Microalgae, Wastewater Treatment, Biochemical Oxygen Demand, Chemical Oxygen Demand, Ammonium-Nitrogen, Phosphate.

\section{Introduction}

Wastewater from settlements contains a significant amount of organic and biogenic substances. Most sewage treatment plants in the Ukraine do not ensure the removal of biogenic substances from wastewater. Insufficiently treated wastewater discharge into surface water and leads to their eutrophication, degradation of aquatic ecosystems, deterioration of water quality and potential danger to human health. Using microalgae in wastewater treatment is a new environmentally friendly biotechnological method. Wastewater provides microalgae necessary nutrients, including carbon, nitrogen and phosphorus, which are assimilated into valuable biomass. (Beuckels et al., 2014; Gómez-Guzmán et al., 2017; GuerraRenteria et al., 2019; Abdel-Raouf et al., 2012).

The usage of microalgae in wastewater treatment has significant advantages in comparison with other methods of removing biogenic substances. Namely: effective and simultaneous removal of nitrogen 
and phosphorus without reagents management facilities, oxygen formation. During the life of microalgae absorb carbon dioxide. Another advantage of microalgae is the integration of wastewater treatment processes and carbon dioxide biofixation, especially in industrialized regions (Molazadeh et al., 2019).

The results of research show that the usage of microalgae of the species Chlorella vulgaris to get the effect of purification of domestic wastewater from nitrogen and phosphorus compounds by more than $95 \%$ (Mayhead et al., 2012). The high efficiency of using Chlorella vulgaris to remove nutrients from industrial wastewater in both aerobic and anaerobic conditions (Amenorfenyo et al., 2019; Szwarc et al., 2020; Khalekuzzaman et al., 2019) and for purification landfill filtrates with high concentrations of ammonium nitrogen and chemical oxygen demand (COD) (Pereira et al., 2016) were proven.

Due to the photosynthesis of microalgae, oxygen is released, which is used by activated sludge for the decomposition of organic substances in the processes of biological wastewater treatment. This allows to reduce energy consumption for traditional wastewater aeration (Muylaert et al.,2019; Wang et al., 2019).

The use of microalgae is a way to dispose of valuable impurities in wastewater. The obtained biomass use as animal feed, biofertilizer, production of biologically active substances in the pharmaceutical and cosmetic industries (Renuka et al., 2015; Wang et al., 2017). Microalgae have received a great deal of attention of the world scientific community, becoming a raw material for biodiesel production, more profitable compared to other sources of biofuels (Borowitzka et al., 2013; Bhatt et al., 2014; Olguín, 2014).

Wastewater is a multicomponent system, the composition of which is constantly changing. This is have influence on the processes of wastewater treatment plants (WWTP). Existing researches about wastewater treatment with microalgae do not provide enough information about the main parameters of this process. Important to know influence temperature of wastewater on this process, because the climate constantly changes have recently been observed in the world. The investigation of the effectiveness of the usage of microalgae Chlorella vulgaris in the processes of wastewater treatment at WWTP is extremely relevant.

\section{Aim}

The purpose of the study is to analyze the work of WWTP in the western region of the Ukraine, determine effectiveness usage of microalgae Chlorella vulgaris in wastewater treatment processes, experimental research of effectiveness wastewater purification (using Chlorella vulgaris) dependency on temperature and indicators: biochemical oxygen demand (BOD), COD, concentration of ammonium nitrogen, phosphates and suspended solids.

\section{Method}

Survey and analysis of the WWTP of the city with a population of about 18,900 inhabitants, located in the western region of Ukraine was performed. Comparisons of concentration of various water quality parameter of effluent and limits in the river Sluch, provided by the municipal water supply and sewerage company, determined efficiency of treatment plant. Experimental studies consisted in adding to wastewater a concentrate of living strain of microalgae Chlorella vulgaris in the amount of 24 liters. The effectiveness of Chlorella vulgaris in wastewater treatment processes was determined by comparing the input and output concentrations of $\mathrm{BOD}_{5}, \mathrm{COD}$, suspended solids, ammonium nitrogen and phosphates in wastewater after 14 and 30 days of microalgae application. Experiments had been performed in WWTP during May-September 2019. The research results of effectiveness of Chlorella vulgaris in wastewater treatment processes depending on temperature wastewater was obtain. 


\section{Results}

\section{Analysis of wastewater treatment plants of the city}

The treatment plant receives a mixture of domestic and industrial wastewater from a city with a population of about 18,900 inhabitants, located in the western region of the Ukraine. Productivity of treatment facilities is $3400 \mathrm{~m}^{3} /$ day.

Wastewater from the city is transport by the system of sewage collectors to the receiving tank of the main sewage pumping station. From the receiving tank those is pumping into the receiving chamber of treatment facilities by submersible pump. The wastewater movement has gravity flow through the plant. The investigated treatment facilities were build in the 70 s of the last century.

The technological scheme of complete biological wastewater treatment consists of the following structures: drum screen, tangential sand traps, clarifiers with natural aeration based on vertical flow tanks with built-in flocculation chamber, corridor type aeration tanks, secondary radial flow settling tank. Sand pulp after sand traps is sent to sand mounds. The treatment plant adopted a pneumatic aeration system for aeration tanks. From the compressor station, located in the administrative building, the required amount of compressed air is supplied to the aeration tanks. Excess activated sludge is sent to sludge drying beds.

Two-stage biopands with natural aeration are used as deep wastewater treatment facilities. Biologically treated wastewater after bioponds discharge into contact tanks through self-flowing pipelines for disinfection using an aqueous solution of sodium hypochlorite.

\section{Determination of the effectiveness of Chlorella vulgaris in wastewater treatment processes}

The effluent is discharged into the Sluch River, which is used for fishery purposes. The values of the maximum allowable discharge and the discharge limit of pollutants in the Sluch River are given in Table 1.

Table 1

The values of the maximum allowable discharge and the discharge limit of pollutants in the Sluch River

\begin{tabular}{|c|c|c|c|}
\hline \multirow{2}{*}{ Parameter } & \multicolumn{2}{|c|}{ The maximum allowable discharge } & The discharge limit \\
\cline { 2 - 4 } & $\mathrm{mg} / \mathrm{l}$ & $\mathrm{g} / \mathrm{hour}$ & 15.00 \\
\hline BOD $_{5}$ & 15.00 & 1713.00 & 80.00 \\
\hline COD & 80.00 & 9136.00 & 2.88 \\
\hline Ammonium-Nitrogen & 2.88 & 328.90 & 3.17 \\
\hline Phosphate & 3.17 & 362.014 & 15.00 \\
\hline Suspended solids & 15.00 & 1713.00 & 290.00 \\
\hline Mineralization & 1000.00 & 114200.00 & 100.00 \\
\hline Chlorides & 290.00 & 33118.00 & 0.10 \\
\hline Sulfates & 100.00 & 11420.00 & 40.0 \\
\hline Nitrites & 0.10 & 11.42 & 0.05 \\
\hline Nitrates & 40.00 & 4568.0 & 0.50 \\
\hline Oil and grease & 0.05 & 5.71 & 57.10 \\
\hline Surfactants & 0.50 & & \\
\hline
\end{tabular}

The results of the treatment plant survey show that the treatment facilities have exhausted their resources and are in unsatisfactory condition. The values of the initial concentrations of $\mathrm{BOD}_{5}, \mathrm{COD}$, suspended solids, ammonium nitrogen and phosphates in wastewater before the use of Chlorella vulgaris are shown in Table 2. 
Quality indicator of wastewater before and after using of Chlorella vulgaris at WWTP

\begin{tabular}{|c|c|c|c|c|}
\hline \multirow{2}{*}{$\begin{array}{c}\text { Quality indicator, } \\
\text { mg/l }\end{array}$} & \multirow{2}{*}{ Influent } & $\begin{array}{c}|c| \\
\text { before usage of } \\
\text { Chlorella vulgaris }\end{array}$ & $\begin{array}{c}\text { after 14 days usage of } \\
\text { Chlorella vulgaris }\end{array}$ & $\begin{array}{c}\text { after 30 days usage of } \\
\text { Chlorella vulgaris }\end{array}$ \\
\cline { 3 - 5 } & 314.85 & 18.80 & 14.20 & 11.80 \\
\hline BOD $_{5}$ & 440.75 & 119.98 & 88.98 & 46.20 \\
\hline COD & 49.06 & 6.10 & 4.50 & 1.00 \\
\hline Ammonium-Nitrogen & 50.65 & 24.26 & 18.10 & 2.17 \\
\hline Phosphate & 344.75 & 32.80 & 24.75 & 12.50 \\
\hline Suspended solids & - & 56.20 & 42.15 & 7.81 \\
\hline Oxidation & - & 3.73 & 4.65 & 7.82 \\
\hline Dissolved oxygen & 6.48 & 7.05 & 7.62 & \\
\hline $\mathrm{pH}$ & & & & \\
\hline
\end{tabular}

Notes: “-”- the indicator was not determined.

Comparison of these values with the data in Table 1 indicates exceeding the normative values. Thus, insufficiently treated wastewater is discharged into the Sluch River.

\section{Dependence of the treatment efficiency of wastewater treatment on temperature. Experimental study}

Experimental research of usage Chlorella vulgaris in wastewater treatment processes were performed. Effectiveness of treatment for $\mathrm{BOD}_{5}, \mathrm{COD}$, concentration of suspended solids, ammonium nitrogen and phosphates depending on wastewater temperature are determined. The results and mathematical equations that describe them is presented in Fig. 1-3.

The effect of treatment varied for $\mathrm{BOD}_{5}$ from $92.77 \%$ to $95.67 \%$ (Fig. 1, a), COD - 73.25-83.73\% (Fig. 1, $b$ ), ammonium nitrogen concentration from 89.13-95.93 \% (Fig. 2, $a$ ), phosphates - 91.60-96.92\% (Fig. 2, b), suspended solids - 93.57-96.84 \% (Fig. 3) within the temperature range of the wastewater from $10.5^{\circ} \mathrm{C}$ to $20^{\circ} \mathrm{C}$. These dependences are described by a linear function that characterizes the general behavior of the obtained data.

\section{Scientific Novelty and Practical Significance}

For the first time, large-scale research of the effectiveness of the usage of microalgae of the species, Chlorella vulgaris on existing WWTP in the western region of Ukraine are presented. The obtained results made it possible to significantly intensify processes of biological treatment facilities at the existing treatment plant. Widespread implementation of the obtained results will reduce the negative impact of treatment plants on the environment.

\section{Conclusions}

The results of the survey and analysis of the existing sewage treatment plant of the city indicate an insufficient degree of wastewater treatment. The effectiveness of the usage of microalgae Chlorella vulgaris at the treatment plant was experimentally proven. Mathematical dependences of the effect of wastewater treatment (using Chlorella vulgaris) on their temperature according to indicators: $\mathrm{BOD}_{5}, \mathrm{COD}$, 
concentration of ammonium nitrogen, phosphates and suspended solids were obtained. Dependencies are described by a linear function that characterizes the general behavior of the obtained data.
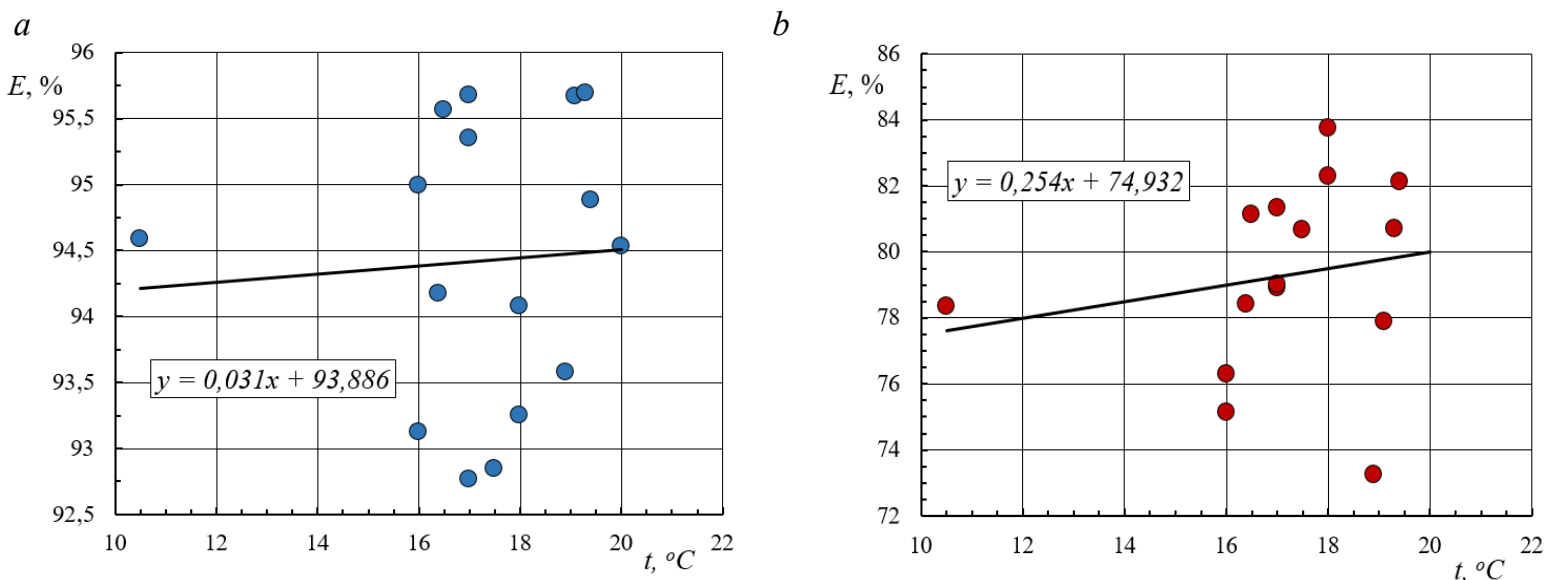

Fig. 1. Dependence of the treatment efficiency $E$ : $a$-for $\mathrm{BOD}_{5}$ and $b-$ for $C O D$ on temperature wastewater with usage Chlorella vulgaris
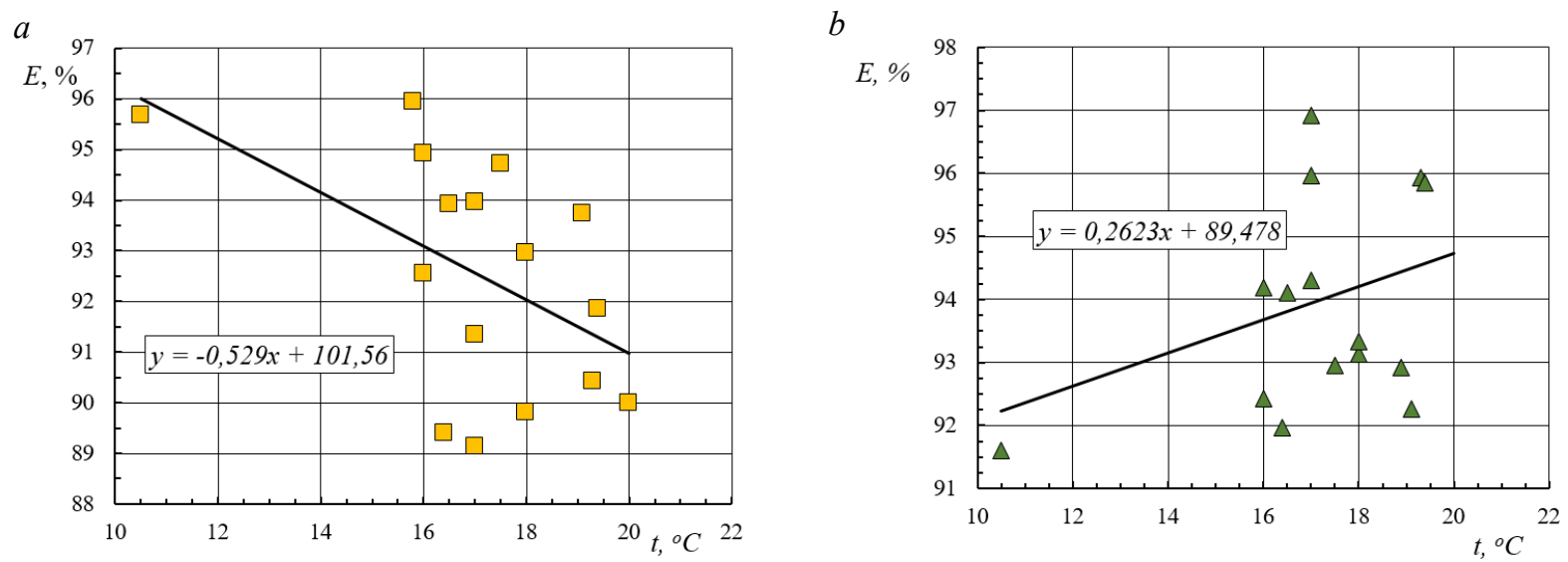

Fig. 2. Dependence of the treatment efficiency E: $a$-for Ammonium-Nitrogen and $b$-for Phosphate on temperature wastewater with usage Chlorella vulgaris

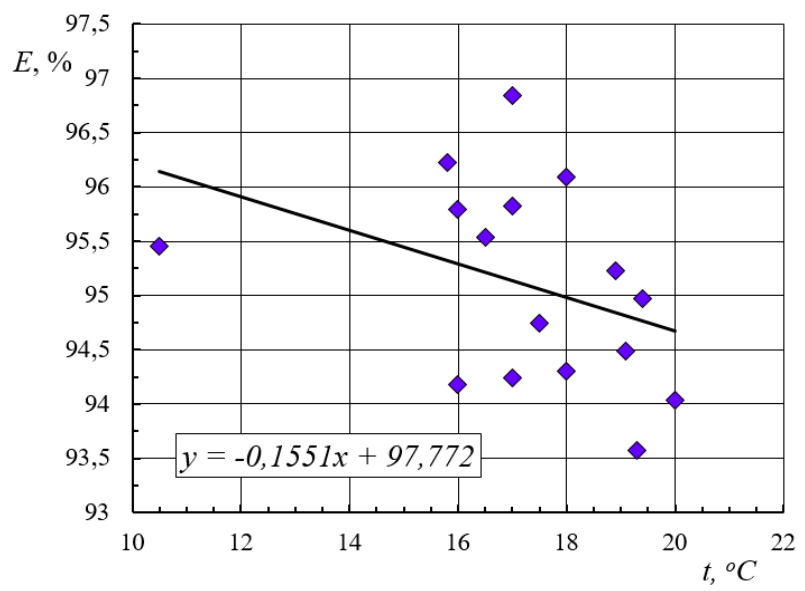

Fig. 3. Dependence of the treatment efficiency E for suspended solids on temperature wastewater with usage Chlorella vulgaris wastewater 


\section{References}

Beuckels, A., Smolders, E., Muylaert, K. (2014) Nitrogen availability influences phosphorus removal in microalgae-based wastewater treatment. Water Research, 77, 98-106. doi: 10.1016/j.watres.2015.03.018

Gómez-Guzmán, A., Jiménez-Magaña, S., Guerra-Rentería, A. S., Gómez-Hermosillo, C., Parra-Rodríguez, F. J., Velázquez, S., Aguilar-Uscanga, B. R., Solis-Pacheco, J., González-Reynoso, O.: Evaluation of nutrients removal $\left(\mathrm{NO}_{3}-\mathrm{N}, \mathrm{NH}_{3}-\mathrm{N}\right.$ and $\left.\mathrm{PO}_{4}-\mathrm{P}\right)$ with Chlorella vulgaris, Pseudomonas putida, Bacillus cereus and a consortium of these microorganisms in the treatment of wastewater effluents. Water Sci. Technol., 76, 49-56 (2017). doi: 10.2166/wst.2017.175

Guerra-Renteria, A. S., García-Ramírez, M. A., Gómez-Hermosillo, C., Gómez-Guzmán, A., GonzálezGarcía, Y., \& González-Reynoso, O. (2019) Metabolic Pathway Analysis of Nitrogen and Phosphorus Uptake by the Consortium between C. Vulgaris and P. aeruginosa. International journal of molecular sciences, 20(8), 1978. https://doi.org/10.3390/ijms20081978

Abdel-Raouf, N., Al-Homaidan, A. A., Ibraheem, I. B. M. (2012) Microalgae and wastewater treatment. Saudi J. Biol. Sci., 19(3), 257-275. https://doi.org/10.1016/j.sjbs.2012.04.005

Molazadeh, M., Ahmadzadeh, H., Pourianfar, H. R., Lyon, S., Rampelotto, P. H.: The Use of Microalgae for Coupling Wastewater Treatment With $\mathrm{CO}_{2}$ Biofixation. Frontiers in bioengineering and biotechnology, 7, 42 (2019). https://doi.org/10.3389/fbioe.2019.00042

Mayhead, E., Silkina, A., Llewellyn, C. A., Fuentes-Grünewald, C. (2018) Comparing Nutrient Removal from Membrane Filtered and Unfiltered Domestic Wastewater Using Chlorella vulgaris. Biology, 7(1), 12. https://doi.org/10.3390/biology7010012

Amenorfenyo, D. K., Huang, X., Zhang, Y., Zeng, Q., Zhang, N., Ren, J., Huang, Q. (2019) Microalgae Brewery Wastewater Treatment: Potentials, Benefits and the Challenges. International journal of environmental research and public health, 16(11), 1910. https://doi.org/10.3390/ijerph16111910

Szwarc, K., Szwarc, D., Zieliński, M. (2020) Removal of biogenic compounds from the post-fermentation effluent in a culture of Chlorella vulgaris. Environmental science and pollution research international, 27(1), 111117. https://doi.org/10.1007/s11356-019-05162-6

Khalekuzzaman, M., Alamgir, M., Islam, M. B., Hasan, M. (2019) A simplistic approach of algal biofuels production from wastewater using a Hybrid Anaerobic Baffled Reactor and Photobioreactor (HABR-PBR) System. PloS one, 14(12), e0225458. https://doi.org/10.1371/journal.pone.0225458

Pereira, S. F. L., Gonçalves, A. L., Moreira, F. C., Silva, T. F. C. V., Vilar, V. J. P., Pires, J. C. M. (2016) Nitrogen Removal from Landfill Leachate by Microalgae. Int. J. Mol. Sci., 17(11), 1926. https://doi.org/10.3390/ijms17111926

Muylaert, K., Beuckels, A., Depraetere, O., Foubert, I., Markou, G, Vandamme, D. (2015) Wastewater as a Source of Nutrients for Microalgae Biomass Production. In.: Moheimani, N.R., McHenry, M.P., de Boer, K., Bahri, P. (Eds.). Biomass and Biofuels from Microalgae: Advances in Engineering and Biology. Springer, Cham, pp. 75-94. doi:10.1007/978-3-319-16640-7_5

Wang, Z., Gao, M., Wei, J., M,a K., Zhang, J., Yang, Y., Yu, S. (2016) Extracellular polymeric substances, microbial activity and microbial community of biofilm and suspended sludge at different divalent cadmium concentrations. Bioresour. Technol., 205, 213-221. doi: 10.1016/j.biortech.2016.01.067

Wang, J. H., Zhang, T. Y., Dao, G. H., Xu, X. Q., Wang, X. X., Hu, H. Y. (2017) Microalgae-based advanced municipal wastewater treatment for reuse in water bodies. Applied microbiology and biotechnology, 101(7), 2659-2675 (2017). doi:10.1007/s00253-017-8184-x

Renuka, N., Sood, A., Prasanna, R., Ahluwalia, A.S. (2015) Phycoremediation of wastewaters: a synergistic approach using microalgae for bioremediation and biomass generation. Int. J. Environ. Sci. Technol., 12, 14431460. https://doi.org/10.1007/s13762-014-0700-2

Borowitzka, M. A. (2013) Energy from Microalgae: A Short History. In: Borowitzka, M., Moheimani, N. (eds.) Algae for Biofuels and Energy. Developments in Applied Phycology, vol 5. Springer, Dordrecht. https://doi.org/10.1007/978-94-007-5479-9_1

Bhatt, N. C., Panwar, A., Bisht, T. S., Tamta, S. (2014) Coupling of algal biofuel production with wastewater. The Scientific World Journal, 2014, Article ID 210504. https://doi.org/10.1155/2014/210504

Olguín EJ. (2012) Dual purpose microalgae-bacteria-based systems that treat wastewater and produce biodiesel and chemical products within a biorefinery. Biotechnol Adv., 30(5), 1031-10462012. doi:10.1016/j.biotechadv.2012.05.001 
Л. І. Вовк, О. О. Мацієвська, О. В. Жданов

Національний університет “Львівська політехніка", кафедра гідротехніки та водної інженерії

\section{CHLORELLA VULGARIS У ПРОЦЕСАХ ОЧИЩЕННЯ СТІЧНИХ ВОД - ПРАКТИЧНИЙ ДОСВІД}

(с) Вовк Л. І., Мачієвська О. О., Жданов О. В., 2020

Стічні води від населених пунктів містять значну кількість органічних і біогенних речовин. Недостатньо очищені стічні води, що надходять у поверхневі водойми, призводять до їхньої евтрофікації. Очищення стічних вод з використанням мікроводоростей є новим екологічно чистим біотехнологічним методом. Порівняно з іншими методами очищення стічних вод від біогенних елементів застосування мікроводоростей має значні переваги. А саме: ефективне та одночасне видалення азоту та фосфору, відсутність необхідності в реагентному господарстві, утворення кисню. Мікроводорості добре ростуть у стічних водах, з яких поглинають забруднювальні речовини. Метою дослідження $\epsilon$ аналіз роботи та визначення можливості інтенсифікації каналізаційних очисних споруд міста в західній області України з населенням близько 18,900 мешканців. Продуктивність очисних споруд 3400 м$^{3}$ /добу. Експериментальні дослідження полягали у додаванні до стічних вод, що надходять на очисні споруди протягом травня-вересня 2019 р, концентрату живого штаму мікроводостей виду Chlorella vulgaris. Під час досліджень використано результати аналізів стічних вод, проведених хімічною лабораторією комунального водопровідно-каналізаційного підприємства. Результати обстеження та аналізу роботи очисної станції міста свідчать про недостатній ступінь очищення стічних вод. Експериментально доведено ефективність застосування Chlorella vulgaris на очисній станції. Отримано математичні залежності ефекту очищення стічних вод (із застосуванням Chlorella vulgaris) від їх температури за показниками: БСК, ХСК, концентрацією амонійного азоту, фосфатів і завислих речовин. Залежності описуються лінійною функцією, яка характеризує загальну поведінку отриманих даних. Отримані результати дали змогу значно зменшити негативний вплив очисних споруд на довкілля.

Ключові слова: мікроводорості, очищення стічних вод, біохімічние споживання кисню, хімічне споживання кисню, амонійний азот, фосфати. 